\title{
ABO Blood Grouping Lover Co-Relate with Pineapple Lover
}

\author{
Muhammad IQ and Asma R* \\ Institute of Molecular Biology and Biotechnology, Bahauddin Zakariya University, \\ Pakistan
}

*Corresponding author: Asma Rasheed, Institute of Molecular Biology and Biotechnology, Bahauddin Zakariya University, Multan, Pakistan, Email: asmakhana885@gmail.com

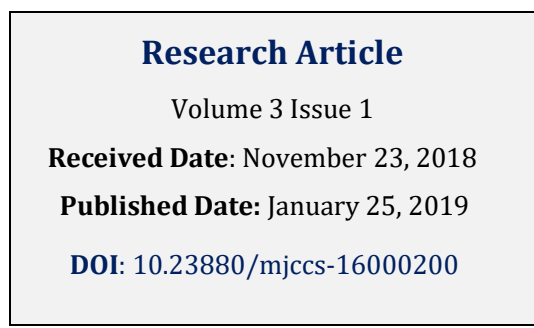

\section{Abstract}

A total number of 185 students of BZU Multan took part in research. The age of the students is about 18 to 22 years. I identified the blood groups of students and took their views about pineapple likeliness. I came to know that most of the students like pineapple. A questionnaire was prepared about pineapple likeliness. It was concluded that most of the students like pineapple.

Key words: Pineapple Lovers; Rh Factor

\section{Introduction}

ABO blood group system was discovered by Karl Landsteiner in 1901. In this system there are 4 blood groups. These are different from each other by antigen which is present on RBCs. man who has antigen A on RBCs has blood group A. if a man has antigen B on RBCs has blood group B. if a man has both antigen RBCs has blood group $\mathrm{AB}$. If both antigens are not present on RBCs the man has blood group 0. In 1930 Karl Landsteiner also discovered the Rh factor on RBCs. his blood group [1].

$\mathrm{Rh}$ positive if a man has not $\mathrm{Rh}$ factor on RBCs his blood group Is Rh negative. I performed an experiment to determine the blood group. I took blood sample and put it on the three slides and mark them as A, B D alternatively. Now I took antiserum A, B and D put them on the three slides alternatively. I saw the blood clotting occur on slide D. No blood clotting occurs on slides A, B. Hence the blood group is 0 positive [2].

Pineapple has sweet, tropical taste. It contains high amount of vitamin C. Pineapples are fat free, cholesterol free and contain low sodium. It gives us energy about 100 calories. It is very important for our health. Many people like to eat it. At the same time many people not like to eat it. Objective of the present study was correlating the blood grouping affiliates with pineapple loving.

\section{Material and Method}

A total number of about 185 students of BZU Multan take parts in research. Age of the students is about 18 to 20 years.

\section{Blood Grouping}

I took blood sample of students MSC biotechnology. After identifying their blood groups I labeled a page of blood groups and took their views about pineapple loving. I examine that the students of blood group A positive B positive $A B$ positive and $O$ positive $O$ Negative most like the pineapple. The students of blood groups A negatives $B$ negative $A B$ negative not match like to eat pineapple but a few of them like to eat pineapple.

\section{Project}

A questioner was prepared about pineapple loving the sweet tropical taste of Pineapple. It contain high amount of vitamin C. pineapple are also fat free cholesterol free 


\section{Medical Journal of Clinical Trials \& Case Studies}

and low sodium. It give us energy about 100 calories. It is very important for our health. Many people like to eat at the same time not like it to eat.

\section{Statistical Analysis}

It was performed by using micro soft word.

\section{Results and Discussion}

The total strength of A positive blood group is 31 in which 14 boys and 17 girls. The total strength of $A$ -negative is one boy and one girl. The total strength of $B$ positive is 58 in which 9 boys and 49 girls similarly the B negative blood group has total strength 5 in which two boys and three girls. $\mathrm{AB}$ positive has 14 total strength in which 3 boys and 11 girls. AB negative has only one girl. 0 positive have total 56strength in which17boys and39 girls the percentage of boys and girls about pineapple loving is given below in the table 1. Questioner based studies have been important outcomes in current research [3-10].

\begin{tabular}{|c|c|c|c|c|}
\hline Blood group & Yes & No & Yes & No \\
\hline & Male & Female & Male & Female \\
\hline A+ positive & 22.58 & 38.70 & 16.12 & 22.58 \\
\hline A- negative & 0 & 50 & 50 & 0 \\
\hline B+ positive & 5.17 & 63.79 & 10.34 & 22.41 \\
\hline B- negative & 20 & 40 & 20 & 20 \\
\hline AB+ positive & 18.18 & 45.45 & 9.09 & 27.27 \\
\hline AB- negative & 0 & 100 & 0 & 0 \\
\hline $\begin{array}{c}\text { O+ } \\
\text { positive }\end{array}$ & 14.28 & 28.57 & 14.28 & 41.07 \\
\hline $\begin{array}{c}\text { O- } \\
\text { negative }\end{array}$ & 0 & 60 & 0 & 40 \\
\hline
\end{tabular}

Table 1: Blood grouping correlate with pineapple lovers.

\section{Conclusion}

It was concluded from the present study that pineapple likeliness is maximum for $\mathrm{A}+$ and minimum for A-.

\section{References}

1. Qadir MI, Malik SA (2010) Comparison of alterations in red blood cell count and alterations in hemoglobin concentration in patients suffering from rectal carcinoma undergoing 5-fluorouracil and folic acid therapy. Pharmacology online Nl 3: 240-243.

2. Qadir MI, Noor A (2018) Anemias Rare \& Uncommon Diseases. Cambridge Scholars Publishing, Newcastle, England.

3. Qadir MI, Javid A (2018) Awareness about Crohn's Disease in biotechnology students. Glo Adv Res J Med Medical Sci 7(3): 62-64.

4. Qadir MI, Saleem A (2018) Awareness about ischemic heart disease in university biotechnology students. Glo Adv Res J Med Medical Sci 7(3): 59-61.

5. Qadir MI, Ishfaq S (2018) Awareness about hypertension in biology students. Int J Mod Pharma Res 7(2): 8-10.

6. Qadir MI, Mehwish (2018) Awareness about psoriasis disease. Int J Mod Pharma Res 7(2): 17-18.

7. Qadir MI, Shahzad R (2018) Awareness about obesity in postgraduate students of biotechnology. Int J Mod Pharma Res 7(2): 14-16.

8. Qadir MI, Rizvi M (2018) Awareness about thalassemia in post graduate students. MOJ Lymphology \& Phlebology 2(1): 14-16.

9. Qadir MI, Ghalia BA (2018) Awareness survey about colorectal cancer in students of M Phil Biotechnology at Bahauddin Zakariya University, Multan, Pakistan. Nov Appro in Can Study 1(3): NACS.000514.2018.

10. Qadir MI, Saba G (2018) Awareness about intestinal cancer in university student. Nov Appro in Can Study 1(3). 